\title{
Radiolabeling of cuticular proteins of the brown-winged green bug, Plautia stali Scott (Hemiptera: Pentatomidae)
}

\author{
Fumio Ihara,* Koji Mishiro and Takeru Sato \\ National Institute of Fruit Tree Science, Tsukuba, Ibaraki 305-8605, Japan
}

(Received 19 September 2001; Accepted 18 January 2002)

\begin{abstract}
Fourth-stadium nymphs of the brown-winged green bug, Plautia stali, were orally labeled with $\left[{ }^{35}\right.$ S $]$ cysteine. We then measured the levels of radioactivity in the fourth- and last-stadia exuvia. Levels of radioactivity in the exuvia increased with increasing doses of $\left.{ }^{35} \mathrm{~S}\right]$ cysteine. The radioactivity levels of labeled exuvia treated with $\mathrm{KOH}$ suggested that the $\left[{ }^{35} \mathrm{~S}\right]$ cysteine was incorporated into cuticular proteins. The degradation pattern of labeled exuvia by bovine pancreas protease and crude enzyme solutions prepared from entomopathogenic fungi suggested that radiolabeled exuvium can be used as a substrate for cuticle-degrading enzymes.
\end{abstract}

Key words: Plautia stali, cuticular proteins, radiolabel, $\left[{ }^{35}\right.$ S $]$ cysteine

\section{INTRODUCTION}

Entomopathogenic fungi are being examined for their potential to serve as microbial pest control agents. Experimentation to select the most suitable fungus with high pathogenicity toward the target insect is an important step in the development of a microbial pesticide. The pathogenicity of entomopathogenic fungi has been estimated by bioassay in target insects such as the Eastern tent caterpillar, Malacosoma americanum (Leathers and Gupta, 1993), the vine weevil, Otiorhynchus sulcatus (Moorhouse et al., 1993), the pear psylla, $\mathrm{Ca}$ copsylla pyricola (Puterka et al., 1994), the coffee berry borer, Hypothenemus hampei (Varela and Morales, 1996), the brown citrus aphid, Toxoptera citricida (Poprawski et al., 1999), and the Mexican fruit fly, Anastrepha ludens (Lezama-Gutierrez et al., 2000). Entomopathogenic fungi to control the brown-winged green bug, Plautia stali Scott, have been selected by Ihara et al. (2001). Using these bioassays, one can directly estimate the pathogenicity of entomopathogenic fungi toward target insects. However, a large number of target insects must be reared for such studies. In addition, the estimation of pathogenicity by bioassay takes quite a long time. These facts are obstacles for the selection of useful entomopathogenic fungi by bioassay. To overcome them, other methods for estimating pathogenicity have been investigated. Rath et al. (1995) examined the correlation between pathogenicity and spore surface antigens of Metarhizium anisopliae. The activity of cuticle-degrading enzymes of entomopathogenic fungi has also been related to fungal pathogenicity, because entomopathogenic fungi invade host insects through the cuticle (e.g., Paris and Ferron, 1979; Silva and Messias, 1986; Clarkson and Charnley, 1996). Gupta et al. (1994) suggested that cuticle degrading enzymes of Beauveria bassiana strains determined not only specific virulence parameters, but also host specificity. However, apart from the work of Bidochka and Khachatourians (1990) and Gillespie et al. (1998), there have been few studies in which insect cuticles have been used as substrates of cuticle-degrading enzymes to estimate pathogenicity.

To develop a method for estimating the pathogenicity of entomopathogenic fungi, we tested radiolabeling of cuticles of $P$. stali with $\left[{ }^{35} \mathrm{~S}\right]$ cysteine. Radiolabeled exuvium thus prepared served as a substrate for the cuticle-degrading enzymes of entomopathogenic fungi.

\section{MATERIALS AND METHODS}

Insects. Laboratory-reared $P$. stali were used in this experiment. In accordance with the method of Moriya et al. (1985), stink bugs were kept at $25^{\circ} \mathrm{C}$

\footnotetext{
* To whom correspondence should be addressed at: E-mail: ihara@affrc.go.jp
} 
with a $16 \mathrm{~L} / 8 \mathrm{D}$ photoregime, and were provided with peanuts, soy beans and distilled water.

Radiolabeling. The radioisotope used in the experiment was L- $\left[{ }^{35} \mathrm{~S}\right]$ cysteine $(29.6 \mathrm{TBq} / \mathrm{mmol}, 370$ $\mathrm{MBq} / \mathrm{ml}$, ICN Biochemicals Inc.). $\left[{ }^{35} \mathrm{~S}\right]$ Cysteine was applied to the stink bugs within 2 weeks after acquisition of the radioisotope.

Nymphs of $P$. stali were put into a plastic petri dish ( $90 \mathrm{~mm}$ diameter $\times 20 \mathrm{~mm}$ depth) lined on the bottom with filter paper. They were maintained at $25^{\circ} \mathrm{C}$ and under a $16 \mathrm{~L} / 8 \mathrm{D}$ photoregime, and were given peanuts and distilled water. A 2-ml plastic cup stuffed with cotton wool was used as a water supply, and $0.5 \mathrm{ml}$ distilled water was added every other day. Radioisotope was added to the water supply when radiolabeling was started. Exuvia of the fourth- and last-stadia nymphs were collected, and washed several times with distilled water. The level of radioactivity of intact exuvium was measured with a liquid scintillation counter (LSC3500, Aloka, Japan). Quenching correction was conducted according to the external standard channel ratio method. The measuring time was $1 \mathrm{~min}$. ASCII (aqueous counting scintillant, Amersham Pharmacia Biotech) was used as the scintillation cocktail. Unlabeled exuvium of the last stadium was used as a control.

Alkaline treatment. To fractionate the cuticle into soluble and insoluble materials, radiolabeled exuvium was treated with $\mathrm{KOH}$ (St. Leger et al., 1986b). One exuvium from a last stadium nymph was put into a $1.5 \mathrm{ml}$-centrifugation tube, and 1.2 $\mathrm{ml}$ of $30 \% \mathrm{KOH}$ was added. The tube was kept in boiling water for $20 \mathrm{~min}$. Insoluble materials were collected by filtration (Grass Microfibre Filters, Whatman), and washed several times with $10 \mathrm{ml}$ of $30 \% \mathrm{KOH}$ and distilled water. Radioactivity levels in the insoluble materials were measured with a liquid scintillation counter.

Protease degradation. Protease (Type I: crude, from bovine pancreas, 10 units $/ \mathrm{mg}$ ) was obtained from Sigma, and dissolved in $50 \mathrm{~mm}$ Tris- $\mathrm{HCl}$ buffer, $\mathrm{pH}$ 8.0.

The last-stadium exuvium was put into an 8.0$\mathrm{ml}$ tube, and $2.0 \mathrm{ml}$ of protease solution was added. The reaction was done at $37^{\circ} \mathrm{C}$ with reciprocal shaking of $100 \mathrm{spm}$. One-hundred-microliter samples were withdrawn at the appropriate times, and radioactivity levels were measured with a liquid scintillation counter. The reaction in $50 \mathrm{~mm}$ Tris-
$\mathrm{HCl}$ buffer was used as a control.

Crude enzyme solution. Two strains of entomopathogenic fungi, $M$. anisopliae strain FRM515 and B. bassiana strain FRB205, were used to prepare an extracellular enzyme solution. They were selected as highly pathogenic fungi to $P$. stali (Ihara et al., 2001).

Conidia were inoculated into $50 \mathrm{ml}$ of a liquid medium containing $0.2 \mathrm{M}$ potassium phosphate buffer, $\mathrm{pH} 7.0,1 \%$ gelatin, $0.3 \% \mathrm{NaCl}$ and $0.3 \%$ $\mathrm{MgSO}_{4} \cdot 7 \mathrm{H}_{2} \mathrm{O}$ (Bidochka and Khachatourians, 1988) in a 200-ml Erlenmeyer flask. The culture was incubated for 5 days at $25^{\circ} \mathrm{C}$ with rotary shaking at $200 \mathrm{rpm}$. After incubation, the mycelia were removed by filtration through a No. 2 filter paper (Advantec, Japan), and hyphal bodies were removed by centrifugation $\left(8,000 \times \mathrm{g}, 20 \mathrm{~min}, 4^{\circ} \mathrm{C}\right)$. The supernatant was used as a crude enzyme solution and stored at $-20^{\circ} \mathrm{C}$ until use. Protease, chitinase and esterase activities in the solution were defined by using Azo dye-impregnated collagen (Bidochka and Khachatourians, 1987), p-nitrophenyl $N$-acetyl- $\beta$-D-glucosaminide (St. Leger et al., 1986a) and $p$-nitrophenyl caproate (Ihara et al., 1991), respectively as substrates. The cell weight of the culture was estimated by filtration through preweighed No. 2 filter paper, then drying of the filter paper at $95^{\circ} \mathrm{C}$ for $4 \mathrm{~h}$ and finally weighing (Bidochka and Khachatourians, 1988).

The procedure for degradation of the labeled exuvium by the crude enzyme solution was almost the same as in the reaction of protease, except the reaction temperature of the enzyme solution was $25^{\circ} \mathrm{C}$. The reaction in the liquid medium was used as a control.

\section{RESULTS AND DISCUSSION}

\section{Incorporation of radioisotope}

$\left[{ }^{35} \mathrm{~S}\right]$ Cysteine was used to radiolabel cuticular proteins of $P$. stali. Five fourth-stadium nymphs within $24 \mathrm{~h}$ after ecdysis were put into a petri dish and provided with radioisotope. The amount of $\left[{ }^{35} \mathrm{~S}\right]$ cysteine supplied to each petri dish varied from 185 to $1,850 \mathrm{kBq}$ (Fig. 1). Radioactivity levels in both fourth- and last-stadium exuvia increased according to the amount of radioisotope used.

We tested the effect of nymphal age on incorporation of radioisotope into exuvia. The periods 
from ecdysis of $P$. stali to the provision of $\left[{ }^{35} \mathrm{~S}\right] \mathrm{cys}-$ teine were set from 0 to 3 days (Fig. 2). When $1,850 \mathrm{kBq}$ of $\left[{ }^{35} \mathrm{~S}\right]$ cysteine was provided to 10 fourth-stadium nymphs in a petri dish, radioactivity levels in the fourth-stadium exuvia decreased as the nymphs aged. However, radioactivity levels in the last-stadium exuvia were nearly the same, regardless of age of the fourth-stadium nymphs at which dosing began. Thus, commencement of labeling at the onset of 10 fourth-stadium nymphs and at a dose of $1,850 \mathrm{kBq}$ in a petri dish were set

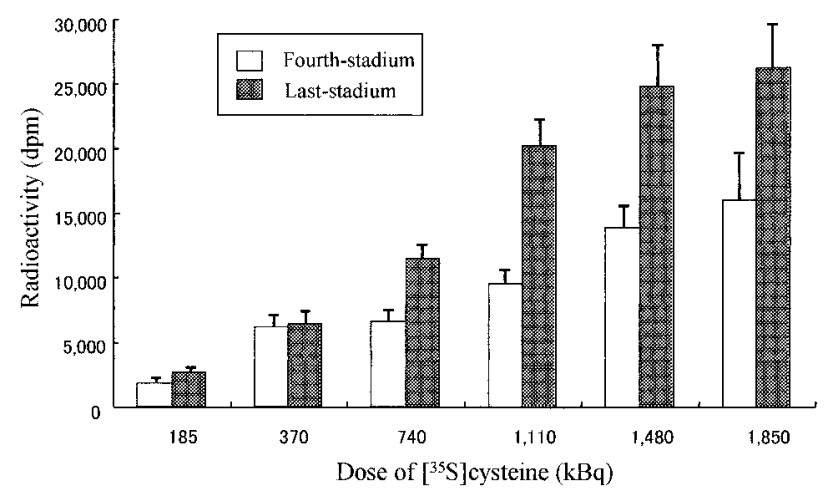

Fig. 1. Dose dependent incorporation of $\left[{ }^{35} \mathrm{~S}\right]$ cysteine into the exuvia of fourth- and last-stadia nymphs. Lines over bars show standard errors. Experiment was replicated 3 times.

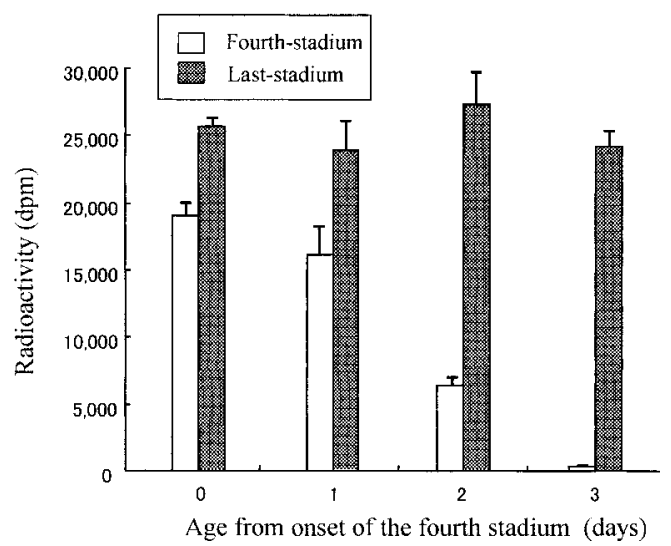

Fig. 2. Effect of nymphal age on incorporation of $\left[{ }^{35} \mathrm{~S}\right]$ cysteine into the cuticle. Lines over bars show standard errors. Each experiment was replicated twice. as the standard experimental conditions. Under these conditions, the mean level of radioactivity in the last-stadium exuvium was 28,893.1 \pm 643.4 dpm $(N=46)$, and the efficiency of utilization of $\left[{ }^{35} \mathrm{~S}\right]$ cysteine was roughly $0.02 \%$. It should be noted that because $\left[{ }^{35} \mathrm{~S}\right]$ cysteine incorporated into the exuvium is insoluble, the radioactivity level obtained by use of a liquid scintillation counter was lower than the actual level. The mean durations of the fourth-stadium nymphs and the fourth- and last-stadium nymphs under the standard experimental conditions were $5.05 \pm 0.16$ days $(N=19)$ and $13.16 \pm 0.28$ days $(N=19)$, respectively. No difference in growth rate between control bugs with water alone and radiolabeled ones was observed $(p>0.17)$. This indicates that $\left[{ }^{35} \mathrm{~S}\right]$ cysteine did not influence growth rate.

\section{Degradation of radiolabeled exuvium}

When last-stadium exuvia labeled with $\left[{ }^{35} \mathrm{~S}\right] \mathrm{cys}-$ teine were treated with hot $30 \% \mathrm{KOH}$, most of the radioactivity was extracted from the exuvia (Table 1), indicating that the radioisotope was incorporated into the alkaline soluble substance. Radiolabeled exuvia were also treated with bovine pancreas protease. The rate of release of radioactivity into the media was incubation time and protease dose dependent (Fig. 3). These results suggest that $\left[{ }^{35} \mathrm{~S}\right]$ cysteine was incorporated into proteins of the cuticle. Furthermore, the results of protease treatment indicate that detection of the radioactivity level of the radiolabeled exuvium is a sufficient indicator of proteolytic degradation, supporting the hypothesis that radiolabeled exuvium can be used as a substrate for protease.

\section{Use of radiolabeled exuvium as a substrate for cuticle-degrading enzymes}

We also investigated the degradation of the radiolabeled exuvium by extracellular enzymes of entomopathogenic fungi. Radiolabeled exuvium was incubated in a crude enzyme solution of ento-

Table 1. Mean radioactivity levels in radiolabeled exuvia before and after hot $\mathrm{KOH}$ treatment

\begin{tabular}{ccc}
\hline $\begin{array}{c}\text { Before treatment } \\
(\mathrm{dpm})(\text { mean } \pm \mathrm{SE})\end{array}$ & $\begin{array}{c}\text { After treatment } \\
(\mathrm{dpm})(\text { mean } \pm \mathrm{SE})\end{array}$ & $\begin{array}{c}\text { Ratio of insoluble fraction } \\
\text { after/before }(\%)\end{array}$ \\
\hline $29,764.6 \pm 3,156.5$ & $4,023.0 \pm 165.5$ & 13.5 \\
\hline
\end{tabular}

$N=10$. 


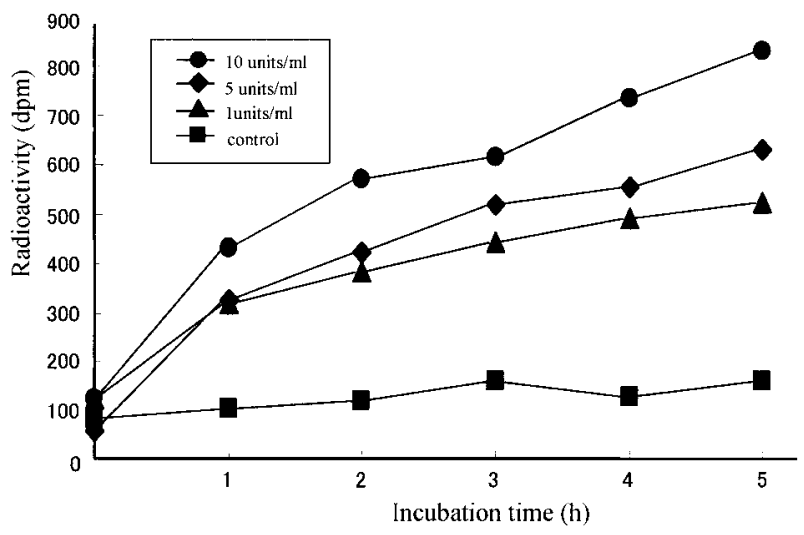

Fig. 3. Detection of solubilized radioactivity released from radiolabeled exuvia by protease treatment.

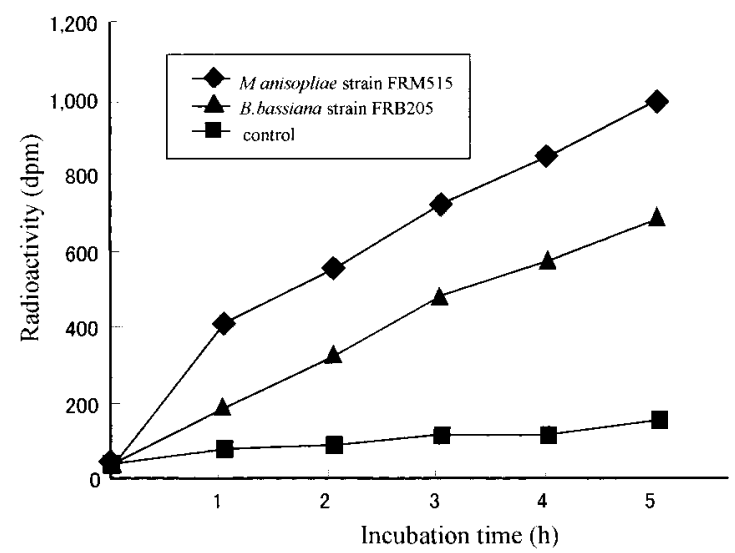

Fig. 4. Solubilization of radioactivity from radiolabeled exuvia degraded by extracellular enzymes of entomopathogenic fungi.

mopathogenic fungus prepared by cultivation of $B$. bassiana strain FRB205 or $M$. anisopliae strain FRM515 (Fig. 4). Radioactivity was released into the media in an incubation time-dependent manner. This suggests that the radiolabeled exuvium is used as a substrate of cuticle-degrading enzymes of entomopathogenic fungi. Interestingly, the rate of degradation of exuvium by the enzyme solution of M. anisopliae strain FRM515 was higher than that of B. bassiana strain FRB205, despite the similarity of the protease activities of the 2 strains (Table 2). M. anisopliae strain FRM515 is more pathogenic to $P$. stali than is B. bassiana strain FRB205 (Ihara et al., 2001), and the slopes of the reaction in Fig. 4 might reflect their relative pathogenicities. We infer that the reaction could be used to estimate the pathogenicity of entomopathogenic fungi.
Table 2. Enzymatic activities of entomopathogenic fungi culture used for degradation of radiolabeled exuvia

\begin{tabular}{|c|c|c|c|c|c|}
\hline \multirow[b]{2}{*}{ Strain } & \multirow[b]{2}{*}{$\mathrm{pH}$} & \multirow{2}{*}{$\begin{array}{l}\text { Weight } \\
\text { of cells } \\
\quad(\mathrm{g})\end{array}$} & \multicolumn{3}{|c|}{ Activity } \\
\hline & & & $\begin{array}{l}\text { Protease } \\
(\mathrm{PU} / \mathrm{ml})\end{array}$ & $\begin{array}{l}\text { Chitinase } \\
\text { (units } / \mathrm{ml} \text { ) }\end{array}$ & $\begin{array}{c}\text { Esterase } \\
\text { (units } / \mathrm{ml} \text { ) }\end{array}$ \\
\hline $\begin{array}{l}\text { B. bassiana } \\
\text { strain FRB205 }\end{array}$ & 6.86 & 0.17 & 2.12 & 3.19 & 0.10 \\
\hline strain FRM515 & 7.10 & 0.23 & 2.09 & 0.27 & ND \\
\hline
\end{tabular}

ND: not detected.

\section{Advantages of using radiolabeled stink bug exu- vium}

Gillespie et al. (1998) radiolabeled cuticle by injecting L- $\left[4,5-{ }^{3} \mathrm{H}\right]$ leucine into pupae of Manduca sexta. Our current report may be the first to label the insect cuticle by a simple oral method, although this is an application of a technique widely utilized to trace food substances in metabolic pathways (e.g., Sorensen and Vinson, 1980). After ecdysis, the stink bug leaves exuvia that are harder than those of other insects, and this offers another advantage in that we can obtain pure cuticles without the need for a purification procedure. Generally, the insect cuticle is differentiated into three layers: epicuticle, exocuticle and endocuticle, from outside to inside. However, the exuvium consists of only epicuticle and exocuticle (Chapman, 1998). Since infection of entomopathogenic fungi is initiated by germination of conidia and penetration of the fungal germ tube into the cuticle of a host, degradation of the epicuticle would be an essential process for entomopathogenic fungi to complete infection. Thus, radiolabeled exuvium might be useful as a substrate of cuticle-degrading enzymes in estimating the pathogenicity of entomopathogenic fungi, although the structures of the intact cuticle and exuvium are different.

Bidochka and Khachatourians (1990) experimented with unlabeled cuticle of the migratory grasshopper, Melanoplus sanguinipes. Enzymatic degradation of cuticle powder was checked by measuring the amounts of soluble amino groups by the ninhydrin reaction. Gillespie et al. (1998) estimated proteolytic activity by using ${ }^{3} \mathrm{H}$-labeled pupal cuticle powder of $M$. sexta. Solubilized radioactivity from the cuticle was detected by liquid scintillation counter after filtration of the aliquot to 
remove insoluble materials. In our study, the intact ${ }^{35} \mathrm{~S}$-labeled exuvium was used as a substrate for enzymatic degradation as substrates, and radioactivity released into the medium was detected directly by a liquid scintillation counter. Our method appears much simpler and easier than the other.

\section{REFERENCES}

Bidochka, M. J. and G. G. Khachatourians (1987) Purification and properties of an extracellular protease produced by the entomopathogenic fungus Beauveria bassiana. Appl. Environ. Microbiol. 53: 1679-1684.

Bidochka, M. J. and G. G. Khachatourians (1988) N-Acetyl-Dglucosamine-mediated regulation of extracellular protease in the entomopathogenic fungus Beauveria bassiana. Appl. Environ. Microbiol. 54: 2699-2704.

Bidochka, M. J. and G. G. Khachatourians (1990) Identification of Beauveria bassiana extracellular protease as a virulence factor in pathogenicity toward the migratory grasshopper, Melanoplus sanguinipes. J. Invertebr. Pathol. 56: 362-370.

Chapman, R. F. (1998) The Insects. 4th ed. Cambridge University Press, Cambridge, pp. 415-440.

Clarkson, J. M. and A. K. Charnley (1996) New insights into mechanisms of fungal pathogenesis in insects. Trends $\mathrm{Mi}$ crobiol. 4: 197-204.

Gillespie, J. P., R. Bateman and A. K. Charnley (1998) Role of cuticle-degrading protease in the virulence of Metarhizium spp. for the desert locust, Schistocerca gregaria. J. Invertebr. Pathol. 71: 128-137.

Gupta, S. C., T. D. Leathers, G. N. El-Sayed and C. M. Ignoffo (1994) Relationships among enzyme activities and virulence parameters in Beauveria bassiana infections of Galleria mellonella and Trichoplusia ni. J. Invertebr. Pathol. 64: 13-17.

Ihara, F., Y. Kageyama, M. Hirata, T. Nihira and Y. Yamada (1991) Purification, characterization, and molecular cloning of lactonizing esterase from Pseudomonas species. J. Biol. Chem. 25: 18135-18140.

Ihara, F., K. Yaginuma, N. Kobayashi, K. Mishiro and T. Sato (2001) Screening of entomopathogenic fungi against brown-winged green bug, Plautia stali Scott (Hemiptera: Pentatomidae). Appl. Entomol. Zool. 36: 495-500.

Leathers, T. D. and S. C. Gupta (1993) Susceptibility of the Eastern tent caterpillar (Malacosoma americanum) to the entomogenous fungus Beauveria bassiana. J. Invertebr. Pathol. 61: 217-219.

Lezama-Gutierrez, R., A. Augusta-De La Luz, J. Molina-
Ochoa, O. Rebolledo-Dominguez, A. R. Pescador, M. Lopez-Edwards and M. Aluja (2000) Virulence of Metarhizium anisopliae (Deuteomycotina: Hyphomycetes) on Anastrepha ludens (Diptera: Tephritidae): laboratory and field trials. J. Econ. Entomol. 93: 10801084.

Moorhouse, E. R., A. T. Gillespie and A. K. Charnley (1993) Laboratory selection of Metarhizium spp. isolates for control of vine weevil larvae (Otiorhynchus sulcatus). J. Invertebr. Pathol. 62: 15-21.

Moriya, S., M. Shiga and M. Mabuchi (1985) A method for successive rearing of the brown-winged stink bug, (Hemiptera, Heteroptera, Pentatomidae). Bull. Fruit Tree Res. Stn. 12: 133-143 (in Japanese with English summary).

Paris, S. and P. Ferron (1979) Study of the virulence of some mutants of Beauveria brongniartii (=Beauveria tenella). J. Invertebr. Pathol. 34: 71-77.

Poprawski, T. J., P. E. Parker and J. H. Tsai (1999) Laboratory and field evaluation of Hyphomycete insect pathogenic fungi for control of brown citrus aphid (Homoptera: Aphidiae). Environ. Entomol. 28: 315-321.

Puterka, G. J., R. A. Humber and T. J. Poprawski (1994) Virulence of fungal pathogens (imperfect fungi: Hyphomycetes) to pear psylla (Homoptera: Psyllidae). Environ. Entomol. 23: 514-520.

Rath, A. C., P. L. Guy and W. R. Webb (1995) Metarhizium spore surface antigens are correlated with pathogenicity. Mycol. Res. 100: 57-62.

Silva, J. C. and C. L. Messias (1986) Virulence of mutants and revertants of Metarhizium anisopliae var. anisopliae toward Rhodnius prolixus. J. Invertebr. Pathol. 48: 368 374.

Sorensen, A. A. and S. B. Vinson (1980) Quantitative food distribution studies within laboratory colonies of the imported fire ant, Solenopsis invicta Buren. Insectes Soc. 28: $129-160$.

St. Leger, R. J., A. K. Charnley and R. M. Cooper (1986a) Cuticle-degrading enzymes of entomopathogenic fungi: Synthesis in culture on cuticle. J. Invertebr. Pathol. 48: $85-95$.

St. Leger, R. J., R. M. Cooper and A. K. Charnley (1986b) Cuticle-degrading enzymes of entomopathogenic fungi: cuticle degradation in vitro by enzymes from entomopathogens. J. Invertebr. Pathol. 47: 167-177.

Varela, A. and E. Morales (1996) Characterization of some Beauveria bassiana isolates and their virulence toward the coffee berry borer Hypothenemus hampei. J. Invertebr. Pathol. 67: 147-152. 